\title{
Influence of variable concentration of ethanol intake on alveolar bone loos in rats periodontitis model
}

\author{
Daniela Martins de Souza ${ }^{a}$, Rosilene Fernandes da Rocha ${ }^{a}$
}

\begin{abstract}
Objective: The aim of this study was to morphometrically evaluate the effect of variable concentration of ethanol consumption on alveolar bone loss associated with ligature-induce periodontitis in rats. Methods: Thirty-six male rats (Wistar, 120 days-old) were randomly divided into four groups of nine animals each. The rats received daily rat chow and administration of water free liquid diet (control), $10 \%$ alcohol diet (10\% ethanol), $20 \%$ alcohol diet (20\% ethanol) or $30 \%$ alcohol diet (30\% ethanol). After anesthesia, cotton ligatures were placed around the cervix of the right upper second molar, leaving the contralateral teeth unligated. After 8 weeks, the rats were sacrificed and the maxillary bones were removed and alveolar bone loss was analyzed by measuring the distance between the cementoenamel junction and the alveolar bone crest at the buccal site of the right upper second molar.

Results: Unligated groups showed no significant differences between each other $(p>0.05)$. In ligated groups, rats receiving $10 \%, 20 \%$ and $30 \%$ ethanol showed significantly greater bone loss compared to control rats.

Conclusion: These results demonstrate that variable concentration of ethanol consumption may increase alveolar bone loss in male rats, independent of dose used, associated with ligature-induce periodontitis in rats.
\end{abstract}

Key words: Ethanol; alveolar bone loss; periodontitis; rats

\section{Influência da variável concentração de etanol ingerido na perda óssea alveolar em modelo de periodontite em ratos}

\section{Resumo}

Objetivo: O propósito deste estudo foi avaliar morfometricamente o efeito de variáveis concentrações de etanol consumido, na perda óssea alveolar associada a periodontite induzida por ligadura em ratos.

Metodologia: Trinta e seis ratos machos (wistar, 120 dias) foram randomicamente divididos em quatro grupos de nove animais. Os ratos receberam diariamente ração e água livremente (controle), 10\% de álcool na dieta (10\% etanol), $20 \%$ de álcool na dieta (20\% etanol) ou $30 \%$ de álcool na dieta (30\% etanol). Após anestesia, ligaduras de algodão foram colocadas entorno da cervical do segundo molar superior direito, mantendo o dente contra lateral sem ligadura. Após 8 semanas, os ratos foram sacrificados e o osso maxilar foi removido e a perda óssea alveolar foi analisada pela mensuração da distancia entre a junção cemento-esmalte e a crista óssea alveolar na face vestibular do segundo molar superior direito.

Resultados: Os grupos sem ligadura não apresentaram diferença estatística entre eles $(p>0,05)$. Nos grupos com ligadura, os ratos que receberam $10 \%, 20 \%$ e $30 \%$ de etanol apresentaram perda óssea significativamente maior que os ratos controle.

Conclusão: Estes resultados demonstram que variáveis concentrações de etanol podem aumentar a perda óssea alveolar em ratos machos, independente da dose usada, associado a periodontite induzida por ligadura em ratos.

Palavras-chave: Ethanol; perda óssea alveolar; periodontite; ratos a Faculdade de Odontologia da UNESP, São José dos Campos, Brazil

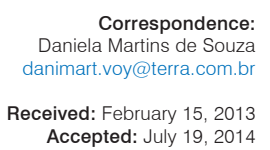

Accepted: July 19,2014

Conflict of Interests: The authors state that there are no financial and personal conflicts of interest that could have inappropriately influenced their work.

Copyright: ( 2014 Souza \& Rocha; licensee EDIPUCRS

Except where otherwise noted, content of this journal is licensed under Creative Commons Attribution 4.0 International license. 


\section{Introduction}

The Global Information System on Alcohol and Health (GISAH) estimated that the harmful use of alcohol results in the death of 2.5 million people annually. There are 60 different types of diseases where alcohol has a significant causal role. It also causes harm to the well-being and health of people around the drinker. In 2005, the worldwide total consumption was equal to 6.13 litres of pure alcohol per person 15 years and older. Unrecorded consumption accounts for nearly $30 \%$ of the worldwide total adult consumption [1].

The list of health problems associated with heavy drinkers, those that exceed moderate levels of alcohol consumption, including increased risk of cardiac arrhythmias, hypertension, stroke, heart disease, cancer, involvement in traffic accidents and situations of violence [2].

Periodontitis involves the destruction of supporting structures of the teeth including the alveolar bone. Periodontitis is an infectious disease with a limited number of specific bacteria as the disease initiators and host factors, which are the major determinants of disease occurrence and severity [3].

There are a large variety of host characteristics that influence the progression of periodontitis, including factors behavioral, social, systemic, genetic and of tooth. The social and behavioral factors include cigarette smoking, socioeconomic status, nutritional status, psychological factors and excessive alcohol consumption [4].

Investigations have suggested that alcohol consumption is associated with increased severity of periodontitis and may be a risk indicator for periodontal disease $[5,6]$. In a crosssectional study involving 13,198 individuals, a moderate but consistent dose-dependent relationship between alcohol consumption and increased severity of the periodontal disease was found [6].

The effects of alcohol on periodontal disease exist and this relation has been explained by biological plausibility through different mechanisms. Chronic alcoholic patients show increased risk for developing severe infection, which appears to be due to altered immune response. Also alcohol has a toxic effect on the liver causing a negative effect on the clotting mechanism [7].

The use of rat models has been applied in the evaluation of periodontal pathogenesis [8] and regarding the influence of risk indicator factors, such as estrogen deficiency [9] and alcohol $[10,11]$ on disease progression. A preview study validated the use of morphometric analysis to evaluate alveolar bone loss in ligature-induced periodontitis in rats, because compared morphometric and histologic procedures and no significant differences were found between the two methods [12]. In addition, analyzed bone loss percentages caused by periodontitis in rats in different locations showed greater bone loss on the buccal side of maxilla [13].

Considering that more studies are required to test the effect of different doses of ethanol of ethanol consumption on periodontitis development, the aim of this study was evaluate the influence of variable concentration of ethanol intake on alveolar bone loss in rats periodontitis model.

\section{Methods}

Animals

Thirty-six adult male Wistar rats (4 months-old) weighing an average of $460 \mathrm{~g}$ were used in the study. All the rats were housed under same conditions and received standard rat chow (Guabi Nutrilador-Mogiana Alimentos, Campinas, SP, Brazil) and water or different solution of ethanol (Ecibra, CETUS, Santo Amaro, SP, Brazil), both ad libitum. The Institutional Animal Research Committee at the University of São José dos Campos (São Paulo, Brazil) approved the protocol.

\section{Experimental groups}

The rats were randomly distributed into four groups of nine animals each. Control group: water and rat chow; $10 \%$ ethanol group: rat chow and liquid diet containing $10 \%$ ethanol, $20 \%$ ethanol group: rat chow and liquid diet containing $20 \%$ ethanol and $30 \%$ ethanol group: rat chow and liquid diet containing 30\% ethanol.

\section{Experimental procedures}

The rats from the $10 \%, 20 \%$ and $30 \%$ ethanol groups were subjected to an adaptation period in which the ethanol concentration was increased until it reached experimental concentrations. A solution containing 5\% ethanol was administered to the $10 \%$ ethanol group for 7 days, the $20 \%$ ethanol group received $5 \%$ and $10 \%$ ethanol for 7 days each, and the $30 \%$ ethanol group received $5 \%, 10 \%$ and $20 \%$ ethanol for 7 days each. After this period, the rats received a diet containing the experimental concentrations for 8 weeks.

After the adaptation period, general anesthesia was induced by intramuscular administration with solution of $13 \mathrm{mg} / \mathrm{kg}$ of $2 \%$ xylazine hydrochloride (Rompum-BayerSão Paulo, SP, Brasil) and 33mg/kg of ketamine (FrancotarVirbac-Roseira, SP, Brasil). To induce alveolar bone loss, cotton ligatures were placed around the cervix of the right upper second molar, leaving the contralateral teeth unligated to serve as control. The ligature was knotted on the buccal side of tooth.

After 8 weeks of alcohol administration, the rats were sacrificed by decaptation, the ligatures were removed and the maxillary bones were fixed in $10 \%$ neutral formalin for $48 \mathrm{~h}$.

\section{Morphometric Analysis}

The maxilla were defleshed and stained with aqueous methylene blue solution (1\%) in order to differentiate bone from teeth.

Alveolar bone loss was evaluated morphometrically by measuring the distance between the cementoenamel junction (CEJ) and alveolar bone crest (ABC) at 2 buccal sites in each maxilla (Fig. 1). The measurements were made along the long axis of the roots at the upper second molar (25X magnification) using the image analysis system Image Tool v.3.0 (UTHSCSA, San Antonio, TX, USA). The mean of these measurements was used as the measurement of alveolar bone loss in each tooth. All measurements were made by an examiner who did not know the group to which the rat pertained. 


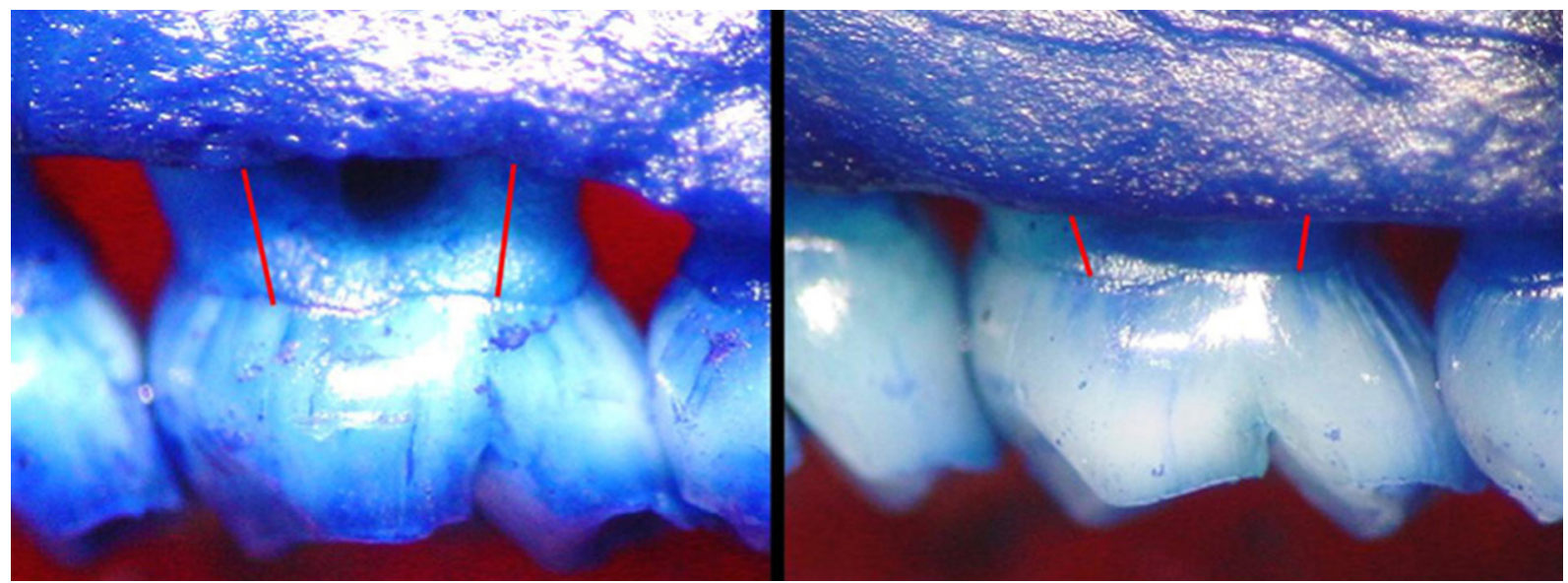

Fig. 1. Photograph of alveolar bone loss morphometrically evaluated by measuring the distance between the cementoenamel junction (CEJ) and alveolar bone crest (ABC) at 2 buccal sites in maxilla ligated (left) and in maxilla unligated (right). The lines indicate the four distances that were measured on each tooth.

In order to obtain sufficient reproducibility of the molar alignment on the image, the teeth should not overlap each other interproximally and the buccal cusp tip of each molar should be superimposed on the corresponding lingual cusp tip.

\section{Statistical Analysis}

During the experimental period, the diet consumed was evaluated as the mean and standard deviation for each group and the results were expressed descriptively. The independent sample $t$ test $(p<0.05)$ was used for comparisons between baseline and final rat body weight in the alcohol groups and control group.

For morphometric analysis, the data were expressed as mean and standard deviation $(\mathrm{mm})$ and the paired $t$ test $(p<0.05)$ was used for intragroup comparisons of alveolar bone loss between ligated and unligated teeth. Intergroup analysis ANOVA and the Tukey test for subsequent multiple comparisons $(\mathrm{p}<0.05)$ were used to separately determine significant differences in alveolar bone loss among the treatment groups for ligated or unligated rats.

\section{Results}

\section{Diet and Weight Analysis}

The $10 \%$ ethanol group consumed an average of $48.57 \pm 1.92 \mathrm{ml} / \mathrm{d}$ of alcohol solution (ethanol represented $4.86 \mathrm{ml} / \mathrm{d}$ ) and $36.72 \pm 3.75 \mathrm{~g} / \mathrm{d}$ provided by normal rat chow. The $20 \%$ ethanol group consumed an average of $43.25 \pm 3.68 \mathrm{ml} / \mathrm{d}$ of alcohol solution (ethanol represented $8.65 \mathrm{ml} / \mathrm{d}$ ) and $31.53 \pm 4.75 \mathrm{~g} / \mathrm{d}$ provided by normal rat chow. The $30 \%$ ethanol group consumed an average of $26.09 \pm 3.29 \mathrm{ml} / \mathrm{d}$ of alcohol solution (ethanol represented $7.83 \mathrm{ml} / \mathrm{d}$ ) and $19.54 \pm 2.49 \mathrm{~g} / \mathrm{d}$ provided by normal rat chow.

The systemic effect of alcohol consumption observed by analysis rat body weight showed that the $10 \%$ ethanol group and $20 \%$ ethanol group gained weight $(10 \%$ ethanol: $30 \mathrm{~g} ; 20 \%$ ethanol: $12 \mathrm{~g})$ significantly $(\mathrm{p}>0.05)$. However, reduction of weight $(30 \%$ ethanol: $-70 \mathrm{~g})$ statistically significant was observed in the rats receiving 30\% ethanol in liquid diet. The control group gained weight significantly $(p>0.05)$ during the experimental period.

A mean weight reduction of $70 \mathrm{~g}$ was observed in the rats receiving very high perceptual of ethanol (30\%). These gradual alterations in body weight resulted in the death of two rats from the group that received $30 \%$ of ethanol in the last week of the experiment.

\section{Morphometric Analysis}

Morphometric analysis showed that cotton ligatures placed around the teeth induced alveolar bone loss, which was confirmed by the greater bone loss $(p<0.05)$ observed in ligated teeth compared to unligated teeth. In unligated teeth, intergroup analysis showed no significant differences between alveolar bone loss values $(\mathrm{p}>0.05)$ among the groups. However, when ligature was placed, analysis revealed higher periodontal bone destruction in rats receiving $10 \%$ ethanol $(1.053 \pm 0.156), 20 \%$ ethanol $(0.983 \pm 0.102)$ and $30 \%$ ethanol $(0.992 \pm 0.113)$, than in rats receiving water (0859 \pm 0.048$)$ (Fig. 2).

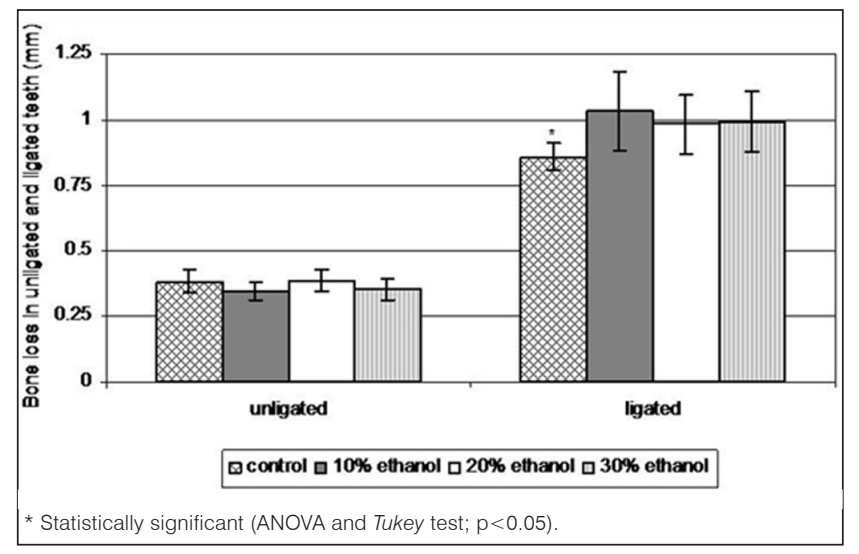

Fig. 2. Mean and standard deviation of alveolar bone loss $(\mathrm{mm})$ in unligated and ligated teeth according to each group. 


\section{Discussion}

Evidence exists that persistent alcohol abuse affects the severity of periodontal disease, when blood levels of gamma-glutamyl transpeptidase (GGTP), a liver enzyme that indicates alcohol consumption were determined [14]. Research suggests that alcohol consumption is associated with increased severity of periodontitis in humans $[5,6,15]$ and increased periodontal disease in rats [10,11,16-18]. However, more recent studies on humans have shown no relation between periodontal disease and alcohol consumption [19-23].

This study is important, because the present results suggest that alcohol increase periodontal bone loss, thus corroborating this positive relation found in humans.

A morphometric analysis of defleshed jaws $[8,10,11]$ was applied to assess the amount of periodontal bone in the rats. Morphometric and histologic procedures were compared for alveolar bone measurement, and no significant differences were found between the two methods when the amount of bone was measured after ligature placement in rats [12]. Souza et al. [13] evaluated morphometrically the bone loss by comparing different locations in experimental periodontitis in rats. The maxilla showed greater bone loss than the mandible, and the bone loss was greater on the buccal side of maxilla.

The most important limitation of this morphometric study was the absence of relating to inflammation and soft tissue observed in histological sections.

The experimental period used in the present study was chosen based on periods ( 8 weeks) used in other works [10, $11,16,17]$. Also, the sample size used (9 rats per group) was the same $[11,17]$ and greater than other studies (6 rats per group) $[16,18]$, that evaluated the influence of ethanol consumption on periodontal disease in rats.

Prior to the experimental period, the ethanol concentration was increased until it reached experimental concentrations. The gradual adaptation to alcohol consumption was important to avoid a negative impact on the metabolism of higher doses continuous.

Tezal et al. [5] used a self-reported questionnaire regarding alcohol consumption observed a significant relationship between alcohol, gingival inflammation and clinical attachment loss, after controls to account for major confounding variables [5]. Amaral et al. [15] showed that alcohol dependence is a associated with periodontal disease, the study evaluated 49 alcoholic and 49 non-alcoholic men in Brazil and observed increased severity of clinical attachment level and probing depth associated with alcohol dependence.

In important cross-sectional study, a moderate but consistent dose-dependent relationship between alcohol consumption and increased severity of periodontal disease was found [6]. Souza et al. [10] demonstrated that the effect of alcohol consumption may enhance periodontal bone loss in ligature-induced periodontitis in female rats in a dosedependent manner. Differently, in this present study none finding were verified associating a dose-dependent effect of alcohol on alveolar bone loss in experimental periodontitis in rats.

Shimazaki et al. [20] verified that the effect of drinking on periodontal condition was limited to individuals presenting deep periodontal pockets associated with more than one-third of their teeth. The study did not find a significant relation between drinking and clinical attachment loss, which may be due to the small sample size and more specifically to the low number of drinkers.

Kongstad et al. [23] related the relationship among alcohol consumption and periodontitis with conflicting results, showing that higher alcohol consumption appears to have an inverse association with attachment loss in men, but not in women. The authors indicated that further assessment was necessary to observe the association between alcohol and periodontitis, establishing prospective cohort studies with participants free of periodontitis at baseline.

Irie et al. [16] suggested that chronic alcohol consumption increased periodontal inflammation, oxidative damage, and TNF-alpha production and had an additive effect on polymorphonuclear leukocyte infiltration and gingival oxidative damage, increasing the severity of periodontal inflammation in the ligature model.

Dantas et al. [18] demonstrated histomorphometrically that short time (12 days) ethanol administration increased the length of the periodontal ligament in rats submitted to ligature induced periodontitis and diminished the alveolar bone volume, which suggest that alcohol consumption (ethanol $25 \%$ ) promotes the progression of this disease in the short term. Additionally, Irie et al. [16] observed by histometric assessment greater distance between the cemento-enamel junction and alveolar bone crest in interproximal side in ethanol group (36\% of total calories in the diet) without ligature and that ethanol did not affect ligature-induced bone resorption.

Souza et al. [10] demonstrated that the effect of alcohol consumption may enhance periodontal bone loss in ligatureinduced periodontitis in female rats in a dose-dependent manner. In the experimental periodontitis groups, rats receiving $20 \%$ ethanol showed significantly greater bone loss compared to control rats or rats receiving $10 \%$ ethanol. Compared with the present study, in female study [10], the $20 \%$ ethanol group consumed an average of $3.68 \mathrm{ml} / \mathrm{d}$ of ethanol, lesser than $10 \%$ ethanol group in male of this study $(4,86 \mathrm{ml} / \mathrm{d}$ of ethanol). These results suggest that the effect of ethanol consumption by day wasn't dependent of genre of the rats, but of volume of ethanol consumed on average during of period experimental.

The reduction in human body weight during chronic alcohol consumption is observed; however, this impact on weight is infrequently observed in rats [24]. In the present study, the systemic effect of alcohol consumption observed by analysis rat body weight showed that groups that consumed $10 \%$ ethanol and $20 \%$ ethanol gained weight, as the control rats. Similarly, Irie et al [16] showed weight gain in ethanol group during the experimental period. However, the present study observed reduction of weight in the rats receiving $30 \%$ 
ethanol associated with nutritional deficiencies as observed in human body weight.

The occurrence of nutritional deficiency can be associated with other causes than alcohol consumption and by itself can affect periodontal tissues, increasing the periodontitis development [25].

The present study was designed to morphometrically evaluate the effect of ethanol consumption on ligatureinduced periodontal bone loss in rats model. The present study showed that ethanol consumption may not affect alveolar bone level regardless of plaque accumulation, but may present statistically greater bone loss resulting from ligature-induced periodontitis in rats.

\section{Conclusion}

In conclusion, this study demonstrated that the effect of ethanol consumption may enhance periodontal bone loss in ligature-induced periodontitis in rats independent of concentration, thus corroborating this positive relation found in humans.

\section{References}

1. Global Information System on Alcohol and Health (GISAH). Availabe at http://www.who.int/gho/alcohol/en/index.html. Accessed Aug 19, 2013.

2. Dufour, M.C. If you drink alcoholic beverages do so in moderation: what does this mean? J Nutr. 2001;131: 552S-61S.

3. Page RC, Offenbacher S, Schroeder HE, Seymour GJ, Kornman KS Advances in the pathogenesis of periodontitis: summary of developments, clinical implications and future directions. Periodontol. 2000 1997; 14: 216-48.

4. Stanford TW, Rees TD. Acquired immune suppression and other risk factors/indicators for periodontal disease progression. Periodontol. 2000 2003;32:118-35

5. Tezal M, Grossi SG, Ho AW, Genco RJ. The effect of alcohol consumption on periodontal disease. J Periodontol. 2001;72:183-9.

6. Tezal M, Grossi SG, Ho AW, Genco RJ. Alcohol consumption and periodontal disease. The third national health and nutrition examination survey. J Clin Periodontol. 2004;31:484-8.

7. Messingham KAN, Faunce DE, Kovacs EJ. Alcohol, injury, and cellular immunity. Alcohol. 2002;28:137-49.

8. Weinberg MA, Bral M. Laboratory animal models in periodontology. J Clin Periodontol. 1999;26: 335-40.
9. Amadei SU, Souza DM, Brandão AAH, Rocha RF. Influence of different durations of estrogen deficiency on alveolar bone loss in rats. Braz Oral Res. 2011:25:538-43

10. Souza DM, Ricardo LH, Kantorski KZ, Rocha RF. Influence of alcohol consumption on the alveolar bone level associated with ligature-induced periodontitis in rats. Braz Oral Res. 2009;23:326-32.

11. Souza DM, Ricardo LH, Prado MA, Prado FA, Rocha RF. The effect of alcohol consumption on periodontal bone support in experimental periodontitis in rats. J Appl Oral Sci. 2006;14:443-7

12. Fernandes MI, Gaio EJ, Oppermann RV, Rados PV, Rösing CK. Comparison of histométrica and morphometric analyses of bone height in ligature-induced periodontitis in rats. Braz Oral Res. 2007; 21:216-21.

13. Souza DM, Prado F de A, Prado M de A, Rocha RF, Carvalho, YR. Evaluation of two morphmetric methods of bone loss percentages caused by periodontitis in rats in different location. J Appl Oral Sci. 2010;18:493-7.

14. Khocht A, Janal M, Schleifer S, Keller S. The influence of gingival margin recession on loss of clinical attachment in alcohol-dependent patients without medical disorders. J Periodontol. 2003; 74:485-93

15. Amaral CD, Luiz RR, Leão $A$. The relationship between alcohol dependence and periodontal disease. J Periodontol. 2008; 79:993-8

16. Irie K, Tomofuji T, Tamaki N, Sanbe T, Eruni D, Azuma T et al. Effects of ethanol consumption on periodontal inflammation in rats. J Dent Res. 2008; 87:456-460.

17. de Souza DM, Rocha RF. Low caloric value of ethanol itself increases alveolar bone loss in ligature-induced periodontitis in male rats. Braz Oral Res. 2009;23:460-6.

18. Dantas AM, Mohn CE, Burdet B ,Zorrilla Zubilete M, Mandalunis PM Elverdin JC, Fernández-Solari J. Ethanol consumption enhances periodontal inflammatory markers in rats. Arch Oral Biol. 2012;57:1211-7.

19. Torrungruang K, Tamsailom S, Rojanasomsith K, Sutdhibhisal S, Nisapakultorn K, Vanichjakvong $\mathrm{O}$ et al. Risk indicators of disease in older Thai adults. J Periodontol. 2005:76:558-65

20. Shimazaki Y, Saito T, Kiyohara Y, Kato I, Kubo M, lida M et al. Relationship between drinking and periodontitis: the Hisayama study. J Periodontol. 2005; 76:1534-41.

21. Okamoto Y, Tsuboi S, Suzuki S, Nakagaki H, Ogura Y,Maeda K, Tokudome $S$. Effects of smoking and drinking habits on the incidence of periodonta disease and tooth loss among Japanese males: a 4-yr longitudinal study. J Periodontal Res. 2006;41:560-6.

22. Jansson L. Association between alcohol consumption and dental health J Clin Periodontol 2008;35:379-84

23. Kongstad J, Hvidtfeldt UA, Gronbaek M, Jontell M, Stoltze K, Holmstrup P. Amount and type of alcohol and periodontitis in the Copenhagen City Heart Study. J Clin Periodontol. 2008;35:1032-9.

24. Lieber CS. Relationships between nutrition, alcohol use, and liver disease. Alcohol Res Health. 2003;27:220-31

25. Boyd, L.D.; Lampi, K.J. Importance of nutrition for optimum health of the periodontium. J Contemp Dent Pract. 2001;2:36-45. 